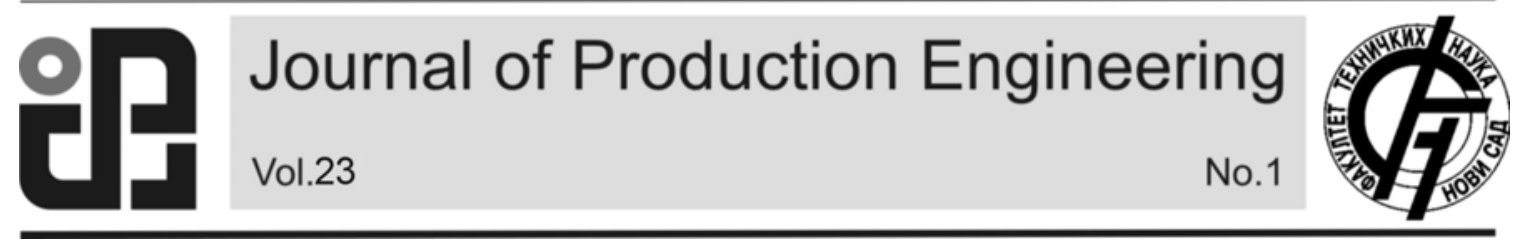

JPE (2020) Vol.23 (1)

András-Tövissi, B., Kajtár, L., Nyers, J.

Original Scientific Paper

\title{
THE IMPACT OF DRAUGHT ON WORK PERFORMANCE IN SPACES WITH CEILING HEATING
}

Received: 01 March 2020 / Accepted: 17 May 2020

\begin{abstract}
Due to the proliferation of different ceiling heating technologies, more and more people are working long hours in rooms with ceiling heating and mechanical ventilation. Optimal thermal comfort is a prerequisite for the efficiency of employees' work. In such a case, it is extremely important to know the combined effect of the radiation temperature asymmetry caused by the warm ceiling and the draught. Research in the literature regarding the combined effect of these two local discomfort factors is incomplete. In the current study, we conducted an experiment involving 20 individuals, 10 women and 10 men, to investigate the effect of draught on work performance in ceiling-heated spaces. The main result of the research is to determine the effect of draughts on the speed and accuracy of work.
\end{abstract}

Key words: Work performance, thermal comfort, radiant thermal asymmetry, draught, joined effect, human subject measurement.

Uticaj promaje na radne performanse u prostorima sa grejanjem plafona. Zbog širenja različitih tehnologija grejanja plafona, sve više $i$ više ljudi provodi više vremena u sobama sa plafonskim grejanjem $i$ mehaničkom ventilacijom. Optimalna toplotna udobnost preduslov je za efikasnost rada zaposlenih. U takvom je slučaju izuzetno važno znati kombinirani učinak asimetrije temperature zračenja uzrokovane toplim plafonom $i$ promajom. Istraživanje u literaturi u vezi kombinovanog dejstva ova dva lokalna faktora nelagodnosti je nepotpuno. $U$ predstavljenoj studiji sproveden je eksperiment u kome je učestvovalo 20 pojedinaca, 10 žena i 10 muškaraca, kako bi se istražio uticaj promaje na radni učinak u toplino zagrejanim prostorima. Glavni rezultat istraživanja je utvrđivanje uticaja promaje na brzinu i tačnost rada.

Ključne reči: Radni učinak, toplotna udobnost, blistava toplotna asimetrija, promaja, zajednički efekat, subjektivni ljudski osećaj.

\section{INTRODUCTION}

The use of ceiling tempering for heating and cooling purposes is becoming more and more widespread and is constantly gaining ground. Mechanical ventilation of spaces with surface tempering is increasingly common. One reason for this is the reduction in the natural filtration due to the ever-increasing airtightness of building structures. Another reason is to avoid condensation in the cooling mode and the resulting damage to the building structure.

Ideal thermal comfort is extremely important for the health and work performance of employees using the building $[1,2]$. On the other hand, the primary purpose of buildings is to serve human use, which also emphasizes the importance of providing ideal thermal comfort [2].

For spaces used by more people, determining the optimal thermal environment is a statistical issue. The most widely used mathematical model describing thermal comfort is the PMV-PPD model, where six parameters influence thermal comfort:

- air temperature,

- air velocity,

- air humidity,

- the average radiation temperature,

- activity level of the occupants,

- and clothing [3].
The PMV model is completed by the local discomfort factors, the effect of which is known only separately [1]. However, in areas with warm ceilings and artificial ventilation, it is highly important to know also the combined effect of the draught and the temperature asymmetry caused by the warm ceiling.

In the current study, we focused on the effect of warm ceilings and draught on work performance. We sought answers to the following questions:

- how does the working speed of women and men change if the draught effect increases from 15\% to $25 \%$, at different radiation asymmetries?

- how does the accuracy of work change under the same circumstances?

\section{METHODS}

\subsection{Methodological background}

The study of the combined effect of local discomfort factors was performed at the Macskásy Comfort and Air Conditioning Laboratory of Budapest University of Technology and Economics.

In the joint measurement of the local discomfort factors, the effect of the hot ceiling and the draught parameter pairs on the thermal comfort was investigated while keeping the thermal environment neutral according to the PMV model.

During the experiment, an external temperature of - 
$15{ }^{\circ} \mathrm{C}$ was assumed, and the internal temperature of the walls was set at $20.5 \mathrm{C}$. The space underneath the measurement chamber was presumed to be tempered, so the floor temperature was also assumed to be $20.5^{\circ} \mathrm{C}$. A temperature asymmetry of 5,7,10,12 and $15{ }^{\circ} \mathrm{C}$ between the floor and the ceiling was obtained with respect to the surface temperature of the floor. The stationary state of the measuring chamber throughout the whole experiment was ensured by inflow of cooler air. A ceiling diffuser was used for this purpose, because it is a very common solution in the current construction practice. The used blower unit has adjustable blades and flow deflector, so we could adjust the symmetry, orientation and character of the inflow air. Instrumental measurements and visualization experiments were performed on the air jet. When examining the parameter groups, we made sure that in the middle of the space, at a height of 1.1 meters, the parameter groups met the basic assumptions of measurement, ie the PPD value must always be below $6 \%$ and the DR value must be $15 \%$ or $25 \%$, depending on the experiment.

\subsection{Instrument measurements}

The spatial distribution of the factors influencing thermal comfort was measured in the measuring room with a floor area of $4 \times 4 \mathrm{~m}$ and a height of $3 \mathrm{~m}$. Measurements were made in four planes: $0.15 \mathrm{~m}$ - ankle level, $0.45 \mathrm{~m}$ - knee level, $1.1 \mathrm{~m}$ - height of sitting person, $1.7 \mathrm{~m}$ - height of standing person. The point at the center of the measurement plane is the average of 5 measurement points as described in section 2.1.2. The parameters affecting the thermal comfort were partly measured and partly calculated. (Tab. 1) shows the various parameters and their associated measurement errors.

During the measurement, a mechnaical venting system was used as shown on fig. 1 . and 2 . In order to achieve a thermally stationary state, the fresh inflow air is colder than the indoor air.

PMV was calculated from other measured parameters, according to ISO 7730 [4]. When we designed the experiment, our goal was to keep the PMV at an optimal interval $(-0.2 .0 .2)$ at 1.1 meters in the center of the space at all times.

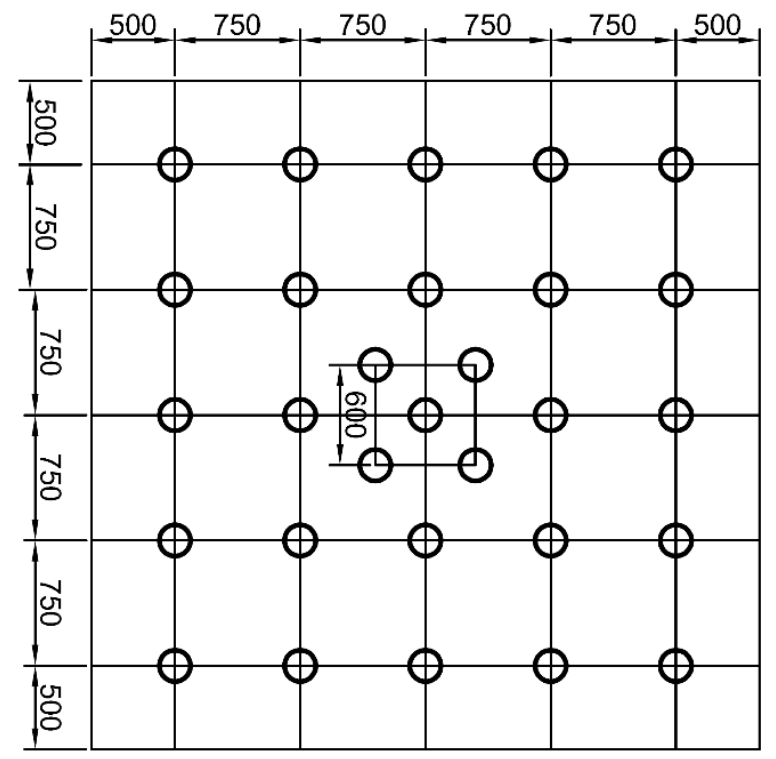

Fig. 2. Layout of the comfort chamber

\begin{tabular}{l|l|l}
\hline Parameter & Measured/Calculated & Error of measurement \\
\hline Air and mean rad. temperature & Measured & $0,1{ }^{\circ} \mathrm{C}$ \\
Air velocity & Measured & $0,03 \mathrm{~m} / \mathrm{s}+0,04$ Measured value \\
Air humidity & Measured & $1,8 \%+0,007$ Measured value \\
Thermal insulation of clothing & Calculated & - \\
Metabolic rate & Calculated & - \\
Intensity of turbulence & Calculated & - \\
PMV & Calculated & - \\
PPD & Calculated & - \\
\hline
\end{tabular}

Table 1. Measured and calculated parameters

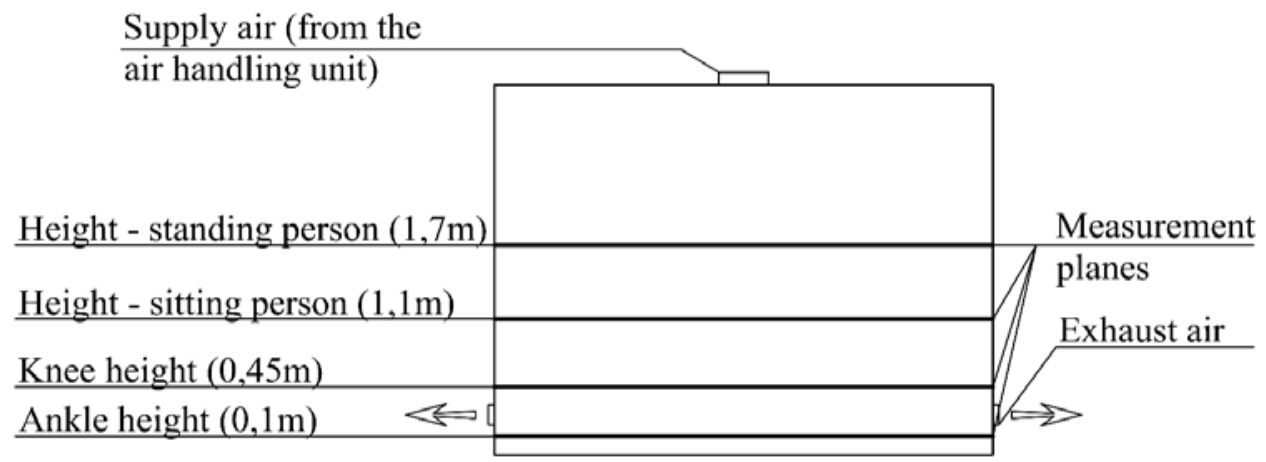

Fig. 1. Section of the comfort chamber

The greatest difference due to the inhomogeneity of the space is noticeable in the distribution of DR, since the mean value of the area marked with the center of the space, is significantly different from the draught value measured in the area near the wall.

For each parameter pair of asymmetry and draught, the condition is that the PPD value remains below 6\% and that the asymmetric radiant temperature difference 
between the floor and ceiling, and the DR value showing draught effect can be maintained at the planned value.

The best way to evaluate the rate of dissatisfaction caused by the warm ceiling with a draught effect of $15 \%$ and $25 \%$, was to perform human subject tests.

\subsection{Human subject measurements}

The human subject measurements were made in the comfort chamber shown on fig. 1. and fig. 2.

During the measurement series, several experiments were performed regarding thermal comfort. The human subjects assessed their dissatisfaction rate with the hot ceiling by using a continuous scale between 0 and 1,0 meaning a dissatisfaction of $0 \%$, and 1 meaning a dissatisfaction of $100 \%$.

All measurements considered the literature-based methodology used in human subject measurements [2, 5-10].

Table 2 shows the methodology used throughout the human subject experiments:

\begin{tabular}{|l|l|}
\hline Number of subjects & 20 subjects: 10 men, 10 women \\
\hline Number of examined cases & 10 cases: 5 thermal asymmetries, 2 DR values \\
\hline Duration of measurement & 3 hours (one comfort environment for each measurement) \\
\hline Order of the comfort environments & Random \\
\hline
\end{tabular}

Table 2. Methodology of the human subject measurements

During the measurements, acoustic disturbances were excluded. Due to the high air exchange rate, the quality of the indoor air did also not cause any dissatisfaction. Furthermore, much attention was paid to eliminating any acoustic discomfort and providing appropriate visual comfort.

One measurement session consisted of a total of six repetitive measurement blocks, lasting thirty minutes each. The paper-based information collected from individuals through these methods was subsequently processed and analyzed using mathematical methods.

\subsection{Mathematical methodology of the evaluation}

During the evaluation of the results, the relationships between the work performance under different conditions were examined. Throughout the study, two sets of data using two different mathematical approaches were compared at all times. The results were evaluated using the Welch test and the Mann-Whitney exact test. Because of the fact that the nature of these two tests is different, two sets of data could safely be regarded as dependent or independent if the same result was obtained using both methods.

The Welch test (also known as the d-test) is a parametric test from the category of statistical hypothesis tests. The significance level of the test was set at 0.05 .

The Mann-Whitney test is a non-parametric test that operates with rankings of values. Its null hypothesis is that there is an equal (50\%) probability that one randomly selected element from one population will be greater than a randomly selected element from a second population. The confidence interval used in the MannWhitney test was defined as a value of 0.95 .

\section{RESULTS}

The efficiency of human work cannot be properly measured without considering work accuracy and work speed. Also, it is important to take into account the socalled speed-accuracy trade-off phenomenon, which comprises the decrease in speed in favor of accuracy, or vice versa.

The above mentioned work efficiency evaluation factors (speed and accuracy) were determined in a personalized way, fully customized on each human subject. When determining the subject's very own level of efficiency, we focused on the following criteria:

- eliminating the learning effect;

- eliminating thermal comfort disturbances.

Prior to performing the comparative tests, human subjects took the performance tests actually used in the human subject experiment. This had the purpose of eliminating the learning effect. However, these tests were merely used to familiarize the subjects with the tasks. Their results were not considered in the final evaluation of the work performance. On the day following the completion of the familiarization tests, the examined subjects were placed in the environment they found ideal - and in this environment, they performed a total of 4 work performance tests. The average of the last 3 was then taken as reference point in determining the individual work performance level of each human subject in part, regarding work speed and work accuracy.

Table 3. displays the work efficiency of women, men, and all human subjects at a draught effect of $15 \%$ and $25 \%$. The table makes use of the following notations:

- RAD.TH.ASS .: radiant thermal asymmetry, ${ }^{\circ} \mathrm{C}$,

- DR: Draught rate,\%,

- S: Speed of the work -,

- A: Accuracy of the work, -.

The combined effect of draught and radiation asymmetry was also described by equations. Since the approach is not analytical but numerical, the determination of the nature of the equation cannot be asserted with absolute certainty. Therefore, by increasing the degree of the curves fitted to the mean values of the measured points, we showed the improvement of the fit, the increase of the $\mathrm{R}^{2}$ value.

Tables 4 to15. contain equations 1-36, each table shows a second, third, and quadratic equation, and in each case the value of $\mathrm{R}^{2}$, which describes the fit. 


\begin{tabular}{|c|c|c|c|c|c|c|c|c|c|c|c|c|}
\hline \multirow{4}{*}{$\begin{array}{c}\text { RAD. } \\
\text { TH. } \\
\text { ASS. }{ }^{\circ} \mathrm{C}\end{array}$} & \multicolumn{12}{|c|}{ WORK PERFORMANCE } \\
\hline & \multicolumn{4}{|c|}{ WOMEN } & \multicolumn{4}{|c|}{ MEN } & \multicolumn{4}{|c|}{ WOMEN AND MEN } \\
\hline & \multicolumn{2}{|c|}{$\mathrm{DR}=15 \%$} & \multicolumn{2}{|c|}{$\mathrm{DR}=25 \%$} & \multicolumn{2}{|c|}{$\mathrm{DR}=15 \%$} & \multicolumn{2}{|c|}{$\mathrm{DR}=25 \%$} & \multicolumn{2}{|c|}{$\mathrm{DR}=15 \%$} & \multicolumn{2}{|c|}{$\mathrm{DR}=25 \%$} \\
\hline & $S$ & A & $S$ & $\mathrm{~A}$ & $S$ & A & $S$ & A & $\mathrm{S}$ & $\mathrm{A}$ & $S$ & $\mathrm{~A}$ \\
\hline 5 & 0.98 & 0.79 & 0.99 & 0.71 & 0.97 & 0.78 & 0.94 & 0.84 & 0.98 & 0.78 & 0.96 & 0.78 \\
\hline 7 & 0.95 & 0.89 & 0.92 & 0.77 & 0.97 & 0.74 & 0.94 & 0.83 & 0.96 & 0.74 & 0.93 & 0.80 \\
\hline 10 & 0.96 & 0.75 & 0.97 & 0.83 & 0.96 & 0.76 & 0.90 & 0.76 & 0.96 & 0.76 & 0.94 & 0.80 \\
\hline 12 & 1.01 & 0.79 & 0.95 & 0.70 & 0.94 & 0.70 & 0.90 & 0.78 & 0.98 & 0.70 & 0.93 & 0.74 \\
\hline 15 & 0.97 & 0.73 & 0.97 & 0.67 & 0.96 & 0.69 & 0.94 & 0.75 & 0.97 & 0.69 & 0.96 & 0.71 \\
\hline
\end{tabular}

Table 3. Mean values of accuracy and speed in case of women, men and all human subjects, at a draught rate of $15 \%$ and $25 \%$

\begin{tabular}{|c|c|}
\hline$P=0.0001 T A^{2}-0.001 \mathrm{TA}+0.97 ; R^{2}=0.06$ & $(1)$ \\
\hline$P=-0.0007 T A^{3}+0.02 T A^{2}-0.21 \mathrm{TA}+1.56 ; R^{2}=0.78$ & $(2)$ \\
\hline$P=-0.0002 T A^{4}+0.008 T A^{3}-0.09 T A^{2}+0.47 \mathrm{TA}+0.15 ; R^{2}=1$ & $(3)$ \\
\hline
\end{tabular}

Table 4. Speed Women, 15\%

\begin{tabular}{|c|c|}
\hline$P=-0.001 T A^{2}+0.009 \mathrm{TA}+0.8 ; R^{2}=0.42$ & (4) \\
\hline$P=0.0009 T A^{3}-0.03 T A^{2}+0.6 \mathrm{TA}+0.09 ; R^{2}=0.59$ & (5) \\
\hline$P=-0.0007 T A^{4}+0.03 T A^{3}-0.42 T A^{2}+2.58 \mathrm{TA}-4.75 ; R^{2}=1$ & (6) \\
\hline
\end{tabular}

Table 5. Accuracy Women, 15\%

\begin{tabular}{|c|c|}
\hline$P=-0.0005 T A^{2}-0.01 \mathrm{TA}+1.02 ; R^{2}=0.57$ & $(7)$ \\
\hline$P=0.0003 T A^{3}-0.007 T A^{2}+0.07 \mathrm{TA}+0.80 ; R^{2}=0.87$ & $(8)$ \\
\hline$P=-0.00004 T A^{4}-0.004 T A^{3}+0.05 T A^{2}-0.25 \mathrm{TA}+1.46 ; R^{2}=1$ & (9) \\
\hline
\end{tabular}

Table 6. Speed Men, 15\%

\begin{tabular}{|c|c|}
\hline$P=-0.0003 T A^{2}-0.004 \mathrm{TA}+0.8 ; R^{2}=0.79$ & $(10)$ \\
\hline$P=-0.0001 T A^{3}+0.003 T A^{2}-0.03 \mathrm{TA}+0.88 ; R^{2}=0.80$ & $(11)$ \\
\hline$P=0.0003 T A^{4}-0.01 T A^{3}+0.19 T A^{2}-1.12 \mathrm{TA}+3.14 ; R^{2}=1$ & $(12)$ \\
\hline
\end{tabular}

Table 7. Accuracy Men, $15 \%$

$$
\begin{gathered}
P=0.0003 T A^{2}-0.007 \mathrm{TA}+1 ; R^{2}=0.25 \\
P=-0.0002 T A^{3}-0.007 T A^{2}+0.07 \mathrm{TA}+1.18 ; R^{2}=0.86 \\
P=-0.000005 T A^{4}+0.002 T A^{3}+0.02 T A^{2}+0.11 \mathrm{TA}+0.8 ; R^{2}=1
\end{gathered}
$$

Table 8. Speed Women and Men, 15\%

\begin{tabular}{|c|c|}
\hline$P=-0.0003 T A^{2}-0.004 \mathrm{TA}+0.8 ; R^{2}=0.79$ & $(16)$ \\
\hline$P=-0.0001 T A^{3}+0.003 T A^{2}-0.03 \mathrm{TA}+0.88 ; R^{2}=0.80$ & $(17)$ \\
\hline$P=0.0003 T A^{4}-0.01 T A^{3}+0.19 T A^{2}-1.12 \mathrm{TA}+3.14 ; R^{2}=1$ & $(18)$ \\
\hline
\end{tabular}

Table 9. Accuracy Women and Men, 15\%

\begin{tabular}{|c|c|}
\hline$P=0.0009 T A^{2}-0.02 \mathrm{TA}+1.04 ; R^{2}=0.19$ & $(19)$ \\
\hline$P=-0.0005 T A^{3}+0.02 T A^{2}-0.16 \mathrm{TA}+1.44 ; R^{2}=0.51$ & $(20)$ \\
\hline$P=0.0003 T A^{4}-0.01 T A^{3}+0.19 T A^{2}-1.21 \mathrm{TA}+3.63 ; R^{2}=1$ & $(21)$ \\
\hline
\end{tabular}

Table 10. Speed Women, 25\%

$$
\begin{gathered}
P=-0.0003 T A^{2}-0.004 \mathrm{TA}+0.8 ; R^{2}=0.79 \\
P=-0.0001 T A^{3}+0.003 T A^{2}-0.03 \mathrm{TA}+0.88 ; R^{2}=0.80 \\
P=0.0003 T A^{4}-0.01 T A^{3}+0.19 T A^{2}-1.12 \mathrm{TA}+3.14 ; R^{2}=1
\end{gathered}
$$

Table 11. Accuracy Women, 25\% 


\begin{tabular}{|c|c|}
\hline$P=0.001 T A^{2}-0.03 \mathrm{TA}+1.06 ; R^{2}=0.67$ & $(25)$ \\
\hline$P=0.0003 T A^{3}-0.009 T A^{2}+0.07 \mathrm{TA}+0.78 ; R^{2}=0.88$ & $(26)$ \\
\hline$P=-0.0001 T A^{4}+0.006 T A^{3}-0.09 T A^{2}+0.52 \mathrm{TA}-0.15 ; R^{2}=1$ & $(27)$ \\
\hline
\end{tabular}

Table 12. Speed Men, 25\%

\begin{tabular}{|c|c|}
\hline$P=0.0005 T A^{2}-0.019 \mathrm{TA}+0.93 ; R^{2}=0.89$ & (28) \\
\hline$P=6 * 10^{-6} T A^{3}+0.0003 T A^{2}-0.02 \mathrm{TA}+0.93 ; R^{2}=0.89$ & (29) \\
\hline$P=-0.0003 T A^{4}+0.01 T A^{3}-0.14 T A^{2}+0.81 \mathrm{TA}-0.8 ; R^{2}=1$ & (30) \\
\hline
\end{tabular}

Table 13. Accuracy Men, 25\%

\begin{tabular}{|c|c|}
\hline$P=0.001 T A^{2}-0.02 \mathrm{TA}+1.05 ; R^{2}=0.86$ & $(31)$ \\
\hline$P=8 * 10^{-5} T A^{3}+0.004 T A^{2}-0.05 \mathrm{TA}+1.11 ; R^{2}=0.89$ & $(32)$ \\
\hline$P=9 * 10^{4} T A^{4}-0.004 T A^{3}+0.05 T A^{2}-0.35 \mathrm{TA}+1.74 ; R^{2}=1$ & (33) \\
\hline
\end{tabular}

Table 14. Speed Women and Men, 25\%

\begin{tabular}{|c|c|}
\hline$P=-0.0025 T A^{2}+0.02 \mathrm{TA}+0.71 ; R^{2}=0.89$ & (34) \\
\hline$P=0.0004 T A^{3}-0.01 T A^{2}+0.13 \mathrm{TA}+0.41 ; R^{2}=0.95$ & (35) \\
\hline$P=0.0002 T A^{4}-0.0061 T A^{3}+0.08 T A^{2}-0.41 \mathrm{TA}+1.52 ; R^{2}=1$ & (36) \\
\hline
\end{tabular}

Table 15. Accuracy Women and Men,25\%

\section{DISCUSSION}

By analyzing the results presented in Section 3, we examined the impact of the draught change on the combined effect of the hot ceiling and draught. The study was conducted with regard to gender and therefore had the following aspects:

- effect of increased draught on women,

- effect of increased draught on men,

- effect of increased draught on all human subjects.

In each case, the results were reported as a function of asymmetric radiation.

\subsection{Effect of dr on women}

The effect of increasing the draught rate on speed and accuracy in case of women, men and all human subjects is shown in Section 3. In this section, the accuracy and speed values are shown at $15 \%$ and $25 \%$ draught, thus illustrating the effect. Also in this case, the method was the mathematical approach presented in the previous section. The data series were also compared by using the Welch and Mann-Whitney methods, in order to look for significant differences or similarities.

Diagram 1. shows the effect of DR on speed and accuracy on women.

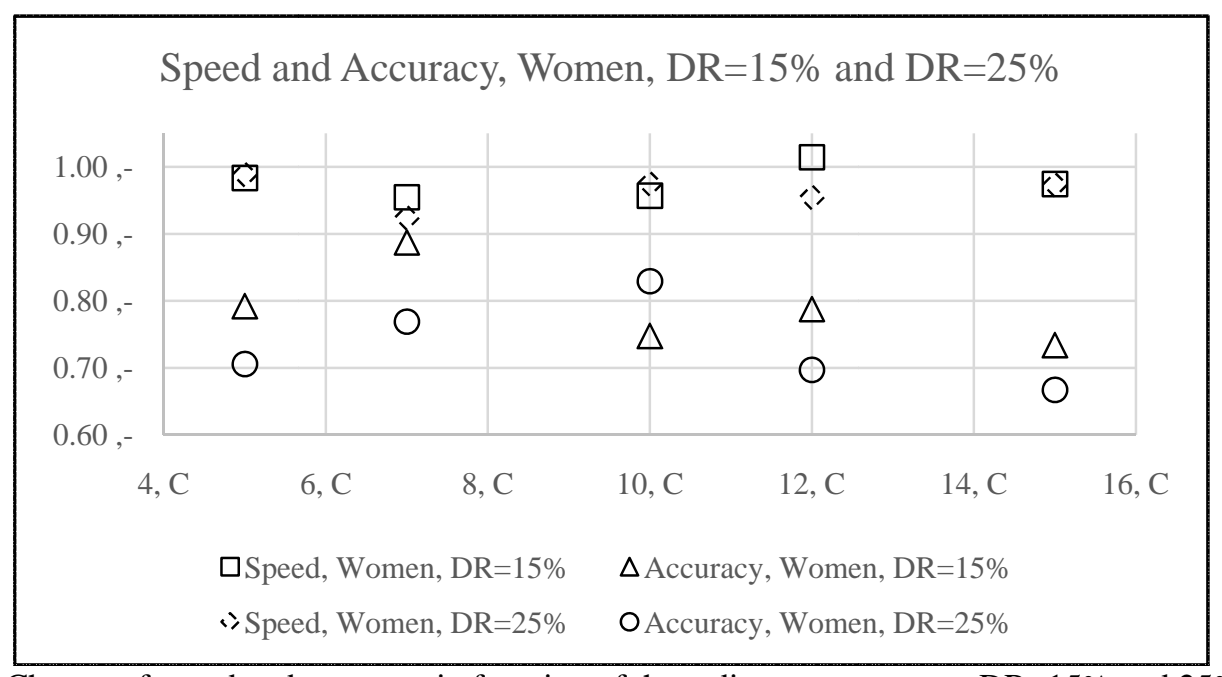

Diagram 1. Change of speed and accuracy in function of the radiant asymmetry - DR=15\% and $25 \%$ - Women

The independence analysis of the velocity and accuracy values for each AS was investigated by the Welsh and Mann-Whitney methods as described in Section 2.4.

While examining the effect of the DR value on the speed and accuracy of work, the independence of the data points measured under the given conditions must also be considered. If the measuring points resulting from the draught effect of DR $=15 \%$ and $\mathrm{DR}=25 \%$ are interdependent, then it can be stated that DR has no effect on the examined parameter, otherwise its opposite is true.

At the asymmetry values of $5,7,10,12,15{ }^{\circ} \mathrm{C}$, the dependence of speed and accuracy on the DR $=15 \%$ and $25 \%$ asymmetry values was investigated. This meant comparing a total of 10 data point groups. It can 
be stated that in the case of women, raising the draught from $15 \%$ to $25 \%$ had no significant effect on their work speed. The only exception was found at the data points measured at $12^{\circ} \mathrm{C}$ asymmetry, where neither the Mann-Whitney nor the Welsh method showed significant differences, but the mean values $\mathrm{DR}=15 \%$ and $\mathrm{DR}=25 \%$ showed slight differences.

A similar method can be used to examine the effect of a draught on the accuracy of work. For women, increasing the draught from $15 \%$ to $25 \%$ had a significant impact on work accuracy. With the exception of the asymmetry value of $10{ }^{\circ} \mathrm{C}$, the accuracy of women's work was higher in all cases at a draught rate of $\mathrm{DR}=15 \%$, considering a given asymmetric radiation value.

\subsection{Effect of dr on men}

Diagram 2 shows the effect of DR on work speed and accuracy in men.

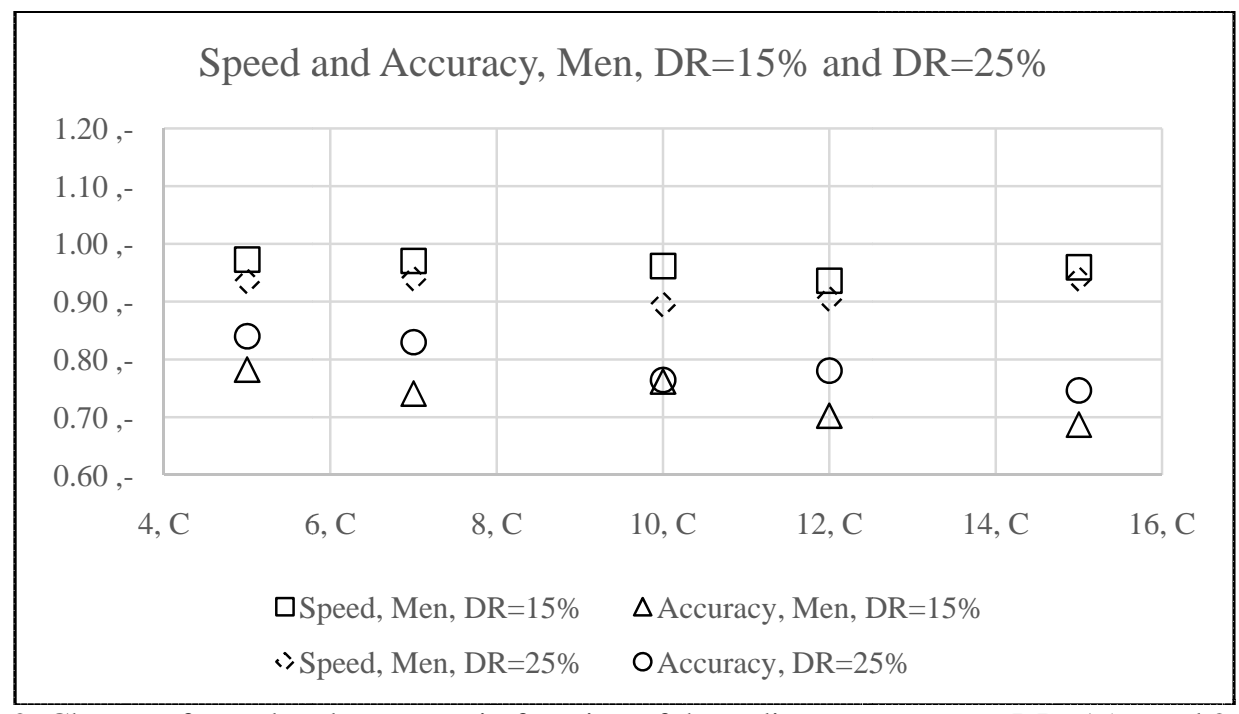

Diagram 2. Change of speed and accuracy in function of the radiant asymmetry -DR=15\% and 25\% - Men

The independence of the velocity and accuracy values for each AS was investigated through the Welsh and Mann-Whitney methods. Again, the independence of 10 measurement sets was compared.

It can be stated that for men, raising the draught from $15 \%$ to $25 \%$ had no significant effect on the speed of work. The only exception is found at the data points measured at $10{ }^{\circ} \mathrm{C}$ asymmetry, where no significant difference can be detected by either Mann Whitney or Welsh method, but the mean values are slightly different for $\mathrm{DR}=15 \%$ and $\mathrm{DR}=25 \%$.
Examining the effect of draught on the accuracy of the work, it can be stated that for men, raising the draught from $15 \%$ to $25 \%$ had a significant effect on the accuracy of the work, except at $10{ }^{\circ} \mathrm{C}$ asymmetry, where no significant effect can be detected. The accuracy of men's work was higher at a given asymmetric radiation value with a draught effect of DR $=25 \%$.

\subsection{Effect of dr on all human subjects}

Diagram 3 shows the effect of DR on speed and accuracy in average, considering both genders.

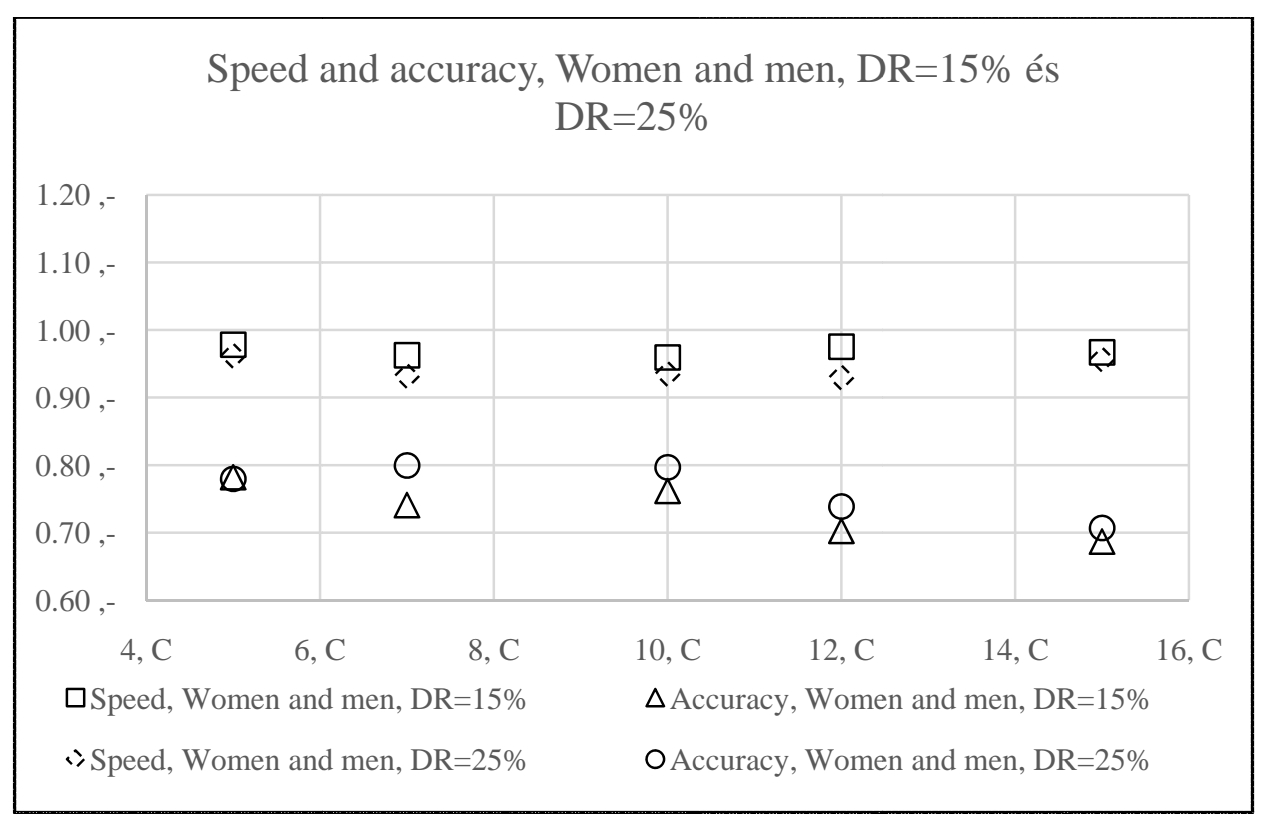

Diagram 3. Change of speed and accuracy in function of the radiant asymmetry -DR $=15 \%$ and $25 \%$ - average 
In order to examine the combined effect of asymmetric radiation and draught, we must consider the speed and accuracy indicators of women and men. Draught dependency, can be investigated by using the methods described in the previous sections. It can be stated that, according to the Welsh test, for all temperature asymmetry values, increasing the draught from DR $=15 \%$ to DR $=25 \%$ has no effect on the work speed of either women, or men. On the other hand, according the Mann-Withney exact test, the same draught increase (from DR $=15 \%$ to DR $=25 \%$ ) effects work speed of both genders only at an asymmetry of 12 ${ }^{\circ} \mathrm{C}$.

Similarly, according to the Mann-Whitney test, raising the draught from $\mathrm{DR}=15 \%$ to $\mathrm{DR}=25 \%$ has no significant effect on the accuracy of work. This cannot be proved with the Welsh test at 7 and $12^{\circ} \mathrm{C}$.

Examining the indices of women and men, in most cases it can be shown that the draught has no effect on the speed and accuracy of the work. This is due to the opposite character of the effects experienced in the case of men and women. In the presence of warm ceilings, women's work was more accurate at lower DR values, while men's work accuracy increased with higher DR values.

\section{CONCLUSION}

When jointly examining the hot ceiling and the draught as a function of asymmetry, the following observations can be summarized:

- for women, raising the draught from $15 \%$ to $25 \%$ has no significant effect on work speed,

- for women, raising the draught from $15 \%$ to $25 \%$ has a significant effect on the work accuracy. Except for the $10{ }^{\circ} \mathrm{C}$ asymmetry value, the accuracy of women's work was always higher at a given asymmetric radiation value at a draught effect of DR $=15 \%$,

- for men, raising the draught from $15 \%$ to $25 \%$ has no significant impact on work speed,

- for men, raising the draught from $15 \%$ to $25 \%$ has a significant effect on work accuracy, except for asymmetry at $10{ }^{\circ} \mathrm{C}$, where no significant effect can be detected. The accuracy of men's work was higher in all cases with a given asymmetric radiation value at a draught effect of DR $=25 \%$,

- according to the Welsh test, increasing the draught from $\mathrm{DR}=15 \%$ to $\mathrm{DR}=25 \%$ has no effect on the working speeds of women and men, for any temperature asymmetry. The Mann-Withney exact test shows that the same draught increase effects both genders' work speed only at an asymmetry of $12{ }^{\circ} \mathrm{C}$,

- according to the Mann-Whitney test, raising the draught from DR $=15 \%$ to $\mathrm{DR}=25 \%$ has no significant effect on the working accuracy. The same cannot be demonstrated with Welsh test at 7 and $12{ }^{\circ} \mathrm{C}$,

- the effect of draughts on the speed and accuracy of work cannot be demonstrated on average because the effects experienced by men and women are the opposite: in the presence of warm ceilings, women work more accurately at lower DR values, while men have a higher work accuracy at higher DR values.

\section{REFERENCES}

[1] Bánhidi, L., Kajtár, L. (2000) Komfortelmélet. BME Technical Press, Budapest,

[2] Wargocki P., Wyon P.D. (2003) Ten questions concerning thermal and indoor air quality effects on the performance of office work and schoolwork. Building and Environment, Issue 51 2012, pp. 234241.

[3] Fanger, P.O. (1970) Thermal Comfort. Danish Technical Press, Copenhagen,

[4] ISO 7730:2005 Standard (2017) Ergonomics of the thermal environment - Analytical determination and interpretation of thermal comfort using calculation of the PMV and PPD indices and local thermal comfort criteria

[5] Toftum J. (2002) Human response to combined indoor environment exposures. Energy and Buildings, Issue 34, pp. 601-606.

[6] Wang J. et. al. (2018) The uncertainty of subjective thermal comfort measurement. Energy and Buildings, Issue 181, pp. 38-49.

[7] Wu X. et. al. (2017) Effect of Supply Air Temperature on Indoor Thermal Comfort in a Room with Radiant Heating and Mechanical Ventilation. Energy Procedia, Issue 121, pp. 206-213.

[8] Lan L., Lian Z. (2010) Application of statistical power analysis - How to determine the right sample size in human health, comfort and productivity research. Building and Environment, Issue 45 , pp. 1202-1213.

[9] Choi J., Yeom D. (2017) Investigation of the relationship between thermal sensation of local body area and whole body in an indoor built environment. Enegy and Buildings, Issue 149, pp. 204-215.

[10] He Y., et.al. (2016) Overall and local thermal sensation and comfort in air-conditioned dormitory with hot-humid climate. Building and Environment, Issue 101 , pp. 102-109.

\section{AKNOWLEDGEMENTS}

This work was partially supported by the Hungarian National Research, Development and Innovation Office (OTKA Number 124777) and the FIKP artificial intelligence -Smart City program.

Thanks to all the companies which have offered material and professional support to the Macskásy climate and comfort laboratory.

\section{Authors:}

Balázs András-Tövissi, László Kajtár, Budapest University of Technology and Economics, Department of Building Services and Process Engineering, Budapest, Hungary

József Nyers, Óbuda University, Doctoral School of Applied Informatics and Applied Mathematics, Budapest, Hungary

E-mail: jnyers1@gmail.com 